\title{
Entrevista com Iara Xavier Pereira
}

Cristina Buarque de Hollanda

\begin{abstract}
Iara Xavier Pereira
Foi militante da ALN [Ação Libertadora Nacional] e exilada política durante a ditadura militar. Retornou ao país pouco antes da Lei da Anistia de 1979 e teve papel chave na articulação da luta pela localização dos mortos e desaparecidos políticos, tendo participado, anos depois, da Comissão Especial Sobre Mortos e Desaparecidos Políticos como assessora.
\end{abstract}

\section{Cristina Buarque de Hollanda}

Professora do Instituto de Estudos Sociais e Políticos da Universidade do Estado do Rio de Janeiro.

E-mail: cristinabuarque@gmail.com

ORCID: https://orcid.org/0000-0002-1600-4044

\section{CRISTINA BUARQUE DE HOLLANDA:}

Muito obrigada por aceitar o convite para conversar comigo, Iara. Eu gostaria muito de te ouvir sobre as mobilizações dos familiares em torno de seus mortos e desaparecidos, ainda durante a ditadura, e, mais tarde, em meados dos anos 1990, sobre a sua experiência na Comissão de Mortos e Desaparecidos.

\section{IARA XAVIER PEREIRA:}

Cada país tem suas peculiaridades. Uma coisa que eu sempre estranhei um pouco no Brasil foi que nós nunca conseguimos fazer um movimento nacional, do ponto de vista formal, de estruturação nacional. Fizemos várias tentativas. Os familiares começam a se mobilizar, como na Argentina e em vários outros lugares, a partir da primeira prisão e do primeiro desaparecido. Geralmente são as mães via advogados que começam a busca e vão se encontrando nessas demandas, nas idas à Brasília, ao Ministério da Justiça, e com um apoio muito importante de D. Paulo Evaristo Arns. Isso já é relatado e documentado, acho que foi em fins de 1973 ou início de 1974 que iniciaram essa busca. Esse grupo foi crescendo. Depois começa também uma mobilização por anistia, através dos Comitês Brasileiros de Anistia [CBAs], que começam a receber os familiares não só dos presos, mas dos mortos e desaparecidos também. Nestes comitês havia ex-presos que começaram a ser fonte de informação para estas famílias. Eu cheguei ao Brasil meses antes da anistia, em maio de 79, após transitar em julgado um último processo meu.

\section{CRISTINA BUARQUE DE HOLLANDA:}

De onde você veio?

\section{IARA XAVIER PEREIRA:}

Bem, eu militei na Ação Libertadora Nacional - ALN, junto com meus pais e irmãos Iuri e Alex [de Paula Xavier Pereira], que foram assassinados em 1972i. Eu estava grávida de Arnaldo Cardoso Rocha, quando ele foi assassinado em março de 1973ii. Como a situação estava muito difícil, a direção da organização decide pela minha ida para o exterior para ter 
a criança, saio do Brasil no final de junho 1973. Após o golpe no Chile [em setembro de 1973], e com a desestruturação da organização, fico exilada até maio de 1979, quando meus sogros avisam que tinha transitado em julgado meu último processo e que eu podia regressar ao Brasil. Nesse período eu estava na Itália, em Milão. Antes disso, eu passei cinco anos em Cuba. Em 78, com o início da abertura, meu sogro pedia: "vem para um país capitalista, quem sabe a gente busca o Arnaldinho [filho de Iara] e fica mais fácil o seu retorno." E minha mãe - e aí uma peculiaridade: toda a minha família foi militante, ela foi presa em janeiro de 1970 e consegue fugir em maio - estava no exterior também, e foi para a Itália. Assim, em maio de 1978, vou para Itália e, em abril de 1979, recebo a notícia que o meu processo havia transitado em julgado; eu fiquei receosa de voltar, porque como a minha família toda foi para o exílio, eu não tinha recursos. A nossa casa foi invadida, tudo foi destroçado. Na Itália, eu até ganhei uma bolsa da Cruz Vermelha, mas o estudo que eu fiz em Cuba não era reconhecido lá. Não tinha acordo educacional, aí eu não pude receber a bolsa de estudo. Minha mãe me apoiou a voltar e em maio de 1979 retorno ao Brasil. Quem me recebeu, além dos familiares, foi o pessoal no Rio - eu sou carioca - e estava a Eny Moreira [advogada], que na época ainda era presidente do CBA [Comitê Brasileiro pela Anistia] lá no Rio. Ela vai com o José Eudes, que era deputado pelo MDB [Movimento Democrático Brasileiro]. Geralmente, os militares já pegavam as pessoas no aeroporto para levar para interrogatório, mas como tinha criança junto ela foi para tentar evitar que eles me retirassem e me levassem direto para o DOPS [Departamento de Ordem Política e Social]. E ela consegue evitar. O pessoal do CBA estava lá no aeroporto, uns jovens, e já me avisaram de uma reunião naquela semana mesmo, que era na antiga Casa do Estudante Universitário, no Flamengo, na Av. Rui Barbosa, onde eram feitas as reuniões. Lá eu encontro vários familiares, nenhum com quem eu tivesse ligação, mas eu consigo contatar a Susana [Lisbôa], que tinha militado comigo, via a Eny. A Susana viu no jornal que eu tinha retornado e procurou a Eny. Ela era uma sobrevivente assim como eu. E a gente se falava por telefone. Eu tinha tido uma informação pela minha tia [Irene da Silva Neunann]. Logo no desembarque, um jornalista me abordou e perguntou o que eu iria fazer dali para frente. Eu disse que queria saber aonde os meus irmãos foram enterrados. A minha tia ouviu isso e disse que sabia aonde eles estavam. Ela disse que um deles, o Iuri, estava com o nome dele, mas o Alex estava com o nome trocado. Ela me disse isso quando saíamos do aeroporto, no carro, a caminho de casa. Assim que os meninos morreram, ela tinha tentando localizar o local de sepultamento procurando nos cemitérios de São Paulo, mas nunca tinha conseguido. Ela era casada com um húngaro que migrou para o Brasil e tinha comprado uma sepultura no cemitério Dom Bosco - naquela época, brasileiro não tinha costume de comprar sepultura com antecedência, mas europeu já tinha. Quando ele falece, ela toma conhecimento do cemitério. Naquela época, para chegar em Perus era uma viagem. Nós fomos em 1979 e para nós já era uma lonjura grande. Era difícil chegar sem carro, de transporte [público] pior ainda. Minha tia voltou uns dias depois do sepultamento do marido para encomendar a lápide dele e aí começou a procurar por meus irmãos ali. Ela foi conversar com o administrador do cemitério. E com o nome e as datas da morte - ela tinha essas informações pelas notícias dos jornais - de cara ela achou o Iuri. O Alex não aparecia. Ela mandou fazer uma lápide com o nome do Iuri e marcou o local de sepultamento. Ela ficou insatisfeita por só ter encontrado o Iuri, que morreu depois do Alex. Ela era católica, ia sempre no Dia de Finados e não desistiu de buscar. Ela era pernambucana, gostava de conversar. Era um lugar afastado, sem muito movimento e ela falava com o administrador que encontrou o Iuri. No final, ele deve ter se condoído. Ele 
disse assim: "ele só tinha esse nome? Como é que a senhora sabe que foi nessa data? A senhora não tem essa notícia do jornal? A próxima vez que a senhora vier, traga o jornal". E, depois, com o jornal em mãos, ele disse: "olha, Dona Irene, será que a polícia não se confundiu? Vamos procurar por esse nome aqui". Não disse que a polícia escondeu. Os militares costumavam fazer uma nota oficial para os jornais poderem publicar, onde geralmente constava o nome completo das vítimas com seus pseudônimos. No caso do Alex, constava a informação de que ele usava identidade falsa com o nome de João Maria de Freitas. E com esse nome ela localizou a sepultura do Alex. Este primeiro administrador com quem minha tia falou devia saber do engodo, foi a conclusão a que nós chegamos. Ela fez tudo isso sozinha, sem orientação, movida pelo sentimento de carinho, de não achar justo que eles ficassem perdidos. Ela disse que não se conformava. Junto com o Alex tinha sido sepultado o Gelson [Reicher], que morreu com ele e também tinha sido enterrado com outro nome. Quando depois procurei os familiares dos companheiros com quem eu tinha militado, vi que os pais do Gelson, que era estudante de medicina, mantinham o quarto do filho como no dia que ele desapareceu: o estetoscópio, a maletinha, tudo no mesmo lugar. Quando minha tia contou toda a história da busca do Alex, eu pensei que essa devia ser uma prática comum dos militares para esconder os nossos desaparecidos, porque a identidade que você usava só você e a pessoa que morava com você conhecia. Os outros não sabiam; então, era um dos meios de você enterrar como indigente, com aquela identidade falsa que a família nunca ia achar. E essa foi uma das formas que eles usaram e foi assim que conseguimos encontrar o primeiro desaparecido, que foi o marido da Susana, o Luiz Eurico [Tejere Lisbôa], porque ela sabia a identidade que ele usava. Quando cheguei ao Brasil em maio de 1979, ela estava morando em Porto Alegre e não podia vir ao Rio. Mas no dia 10 ou 12 de junho [de 1979] ia ter o encontro nacional dos comitês de anistia no Rio, no Colégio Bennett, na [rua] Marquês de Abrantes. Daí esperamos este evento ocorrer para ter nosso reencontro. Compareceram muitos familiares, cerca de cinquenta, o que para a gente era muito. Eu conversei com a Susana, contei a história da localização da sepultura do meu irmão com nome falso e resolvemos ir ao Cemitério em Perus tentar localizar o marido dela a partir da sua identidade falsa e com as possíveis datas do desaparecimento dele. Ela chamou o Ivan Seixas, militante que teve o pai assassinado, e o Sérgio Xavier, que é primo do desaparecido político Carlos Alberto Soares de Freitas. Eu só conhecia a Susana. Eu tinha medo de conversar [com outras pessoas] porque fiquei fora do Brasil e não conhecia ninguém. Eu entrei para a clandestinidade com 16 anos. Ela me assegurava que as pessoas eram de confiança. Terminado o encontro, nós fomos para São Paulo com eles para ir ao cemitério e lá encontramos o Luíz Eurico, sepultado como Nelson Bueno, e também encontramos outros militantes sepultados com os nomes verdadeiros.

\section{CRISTINA BUARQUE DE HOLLANDA:}

Estava tudo documentado?

\section{IARA XAVIER PEREIRA:}

Estava. Eles enterravam igual enterraram o [Carlos] Marighella, no Cemitério de Vila Formosa. Todos como indigentes. Depois de 71, como o cemitério de Vila Formosa estava muito sobrecarregado, eles começaram a levar para Perus. O cemitério ainda era desconhecido, de pouco acesso, conveniente para a repressão. Então coincide também com o maior número de mortos. Quando o familiar chegava em São Paulo, a maioria dos corpos já estava enterrada. Poucos conseguiram ter acesso ao corpo antes de ser sepultado, como foi o caso do meu sogro, que conseguiu sepultar o filho em Belo Horizonte. Quando 
chegamos ao cemitério em Perus, já tinha mudado o administrador. Eu me apresentei como sobrinha da Dona Irene - minha tia que localizou o corpo dos meus irmãos. Já estava aquele administrador que mais tarde ajudou ao apontar aonde estava a vala clandestina, o Antônio [Pires Eustáquio]. Daí aproveitamos esse primeiro contato para fazer buscas em outros anos. Esse administrador foi muito legal porque ele possibilitou essa nossa busca. Nós resolvemos segurar a notícia da localização do Luiz Eurico para denunciar no dia da votação [da Lei da Anistia] porque o [ditador João Baptista] Figueiredo dizia que não tinha desparecido político. Eu me engajei de imediato nesta questão. Eu não sentei e pensei "eu vou procurar sepultura". Mas eu pensei que podia dar respostas a muitas mães.

Começamos, mesmo sem muitos recursos, a montar um levantamento a partir daqueles que estavam em Perus e naquela época era uma viagem para chegar lá. Nós nos concentramos em fazer as denúncias durante o processo de votação da lei de anistia. Elencamos alguns casos: tinha o caso do marido da Susana - que era desaparecido; tinha o caso de ocultação de cadáver com nome falso, que era o do Alex, e achamos outros enterrados ali, mas de nome falso só o Alex até aquela data.

\section{CRISTINA BUARQUE DE HOLLANDA:}

Você conseguiu recuperar os restos mortais do Alex e Iuri?

\section{IARA XAVIER PEREIRA:}

Para retirar os restos mortais do Alex do Cemitério Dom Bosco, lá em 1980, tivemos que entrar com uma ação na justiça para provar que aquela certidão de óbito era falsa. E que João Maria de Freitas era, na verdade, Alex de Paula Xavier Pereira. Quase fui presa porque a juíza queria que eu confirmasse que ele usava aquele nome falso. A juíza me dizia: "mas você pode garantir que ele usava o nome de João Maria de Freitas?", ao que eu respondi que não, porque era a verdade. E eu disse-lhe: "quem pode garantir é o declarante do óbito. Então, a senhora chama esse policial militar que disse que ele era João Maria de Freitas e pergunta de onde ele tirou isso." O [Luiz Eduardo] Greenhalgh me disse para não responder dessa forma para a juíza para eu não ser presa e disse que depois entraria com uma ação de responsabilização contra esse policial que deu a declaração falsa no cartório na certidão de óbito tinha todos os dados como endereço e RG - sobre a identidade do meu irmão, mas não o fez. E essa ação não ocorreu. Ao fazer a exumação em Perus, tivemos vários imprevistos: no local que devia ter restos mortais masculinos, do Alex, eram de uma mulher, e assim tivemos que abrir mais de três sepulturas, o me deixou sempre uma dúvida sobre se aqueles restos mortais eram mesmos do Alex e do Iuriii.

\section{CRISTINA BUARQUE DE HOLLANDA:}

Iara, podemos voltar a falar da movimentação em torno da Lei de Anistia? Você comentou que os familiares se organizaram para denunciar a descoberta que fizeram sobre os desaparecidos no dia da votação da lei. Como foi isso?

Em agosto de 1979, os familiares, os Comitês [Brasileiros] de Anistia começamos a organizar caravanas para ir para Brasília participar da votação do projeto de Anistia. Os estados mais organizados eram São Paulo, Rio e Minas. Do Rio foi um ônibus. Acho que de Minas saíram dois. Fui com o ônibus que saiu do Rio, e quando estávamos na estrada atiraram nos pneus dos nossos ônibus. O motorista começou a ver que estávamos sendo seguidos. E quando estávamos chegando eles tentaram nos intimidar tentando nos tirar da estrada. No ônibus estava a filha do desaparecido Honestino Guimarães, que devia ter uns 5 
ou 6 anos, estavam também mães, esposas. Nós fizemos uma manifestação em frente ao plenário da Câmara: cobrimos parte do tapete verde com cartazes, fotos. O Senador Teotônio Vilela [presidente da Comissão Mista que estudava o projeto de Lei da Anistia do governo] nos recebeu e fizemos a denúncia a ele, de que tínhamos localizado um desparecido político. Ele já tinha dado aquela declaração depois de ter ido aos presídios de que não tinha encontrado nenhum terrorista. Se eu não me engano, o Deputado Fernando Bezerra veio ao nosso encontro também. Porque Pernambuco tem uma tradição de luta também. Nós fizemos denúncia de que os desaparecidos tinham sido mortos e que uma forma que tinham para ocultar [sua identidade] era sepultar como indigente com a documentação falsa que estavam usando. Daí começamos a construir um grupo, que depois se tornaria a Comissão de Familiares dos Mortos e Desaparecidos Políticos. Eu saio do Rio quando o Gilney é solto em dezembro de 1979, a gente resolve morar primeiro em Belo Horizonte. Ele era estudante de medicina e o pessoal consegue a rematrícula dele. Aí ficamos um ano lá, mas ele já sai do presídio enrabichado pelo PT. Tinha um antigo militante, primo de um grande amigo nosso, desse pessoal que tinha sido preso cedo e foi solto em 74. Ele tinha ido viver no Mato Grosso. E visitava Gilney na cadeia e propunha ao Gilney criar o PT na área rural. Gilney foi conhecer e eu não pude, porque estava trabalhando. Como ele saiu com a [liberdade] condicional, não pôde ir para o Mato Grosso neste momento. Eu continuei a ir aos encontros [de familiares] em São Paulo e no Rio, que ficava mais fácil. Até que em março de 1981 decidimos ir para o Mato Grosso. Eu brinco que ele me auto exilou! Eu fui receosa: não conhecíamos ninguém, era muito distante, e estávamos sem dinheiro. Em Minas estávamos mais bem estruturados: tinha a família do Arnaldo, a família dele, os meus pais estavam no Rio, que é perto. Nesse período eu participei menos [dos encontros de familiares], porque tinha que viajar de avião para os deslocamentos e era caríssimo. A gente só foi ter uma estabilidade financeira depois que eu passei num concurso para a Secretaria de Fazenda e ainda levou um tempo. Chegamos a Mato Grosso em março de 81 e só em 1985 é que tivemos estabilidade financeira. E a gente tentou criar uma organização nacional [de familiares]. Mas nunca conseguimos, porque era uma divisão como sempre.

\section{CRISTINA BUARQUE DE HOLLANDA:}

E a divisão era em torno de que motivos?

\section{IARA XAVIER PEREIRA:}

Vários motivos, sobre como seria a direção, como formalizar essa Comissão de familiares, nós tínhamos uma concentração de familiares no Rio, São Paulo e Minas, e em alguns estados tínhamos familiares que participavam. Ficava difícil criar uma organização nacional.

\section{CRISTINA BUARQUE DE HOLLANDA:}

Então não era uma divisão ideológica?

\section{IARA XAVIER PEREIRA:}

Não, foi mais uma dificuldade de conciliar a participação estando os familiares distribuídos em vários estados. Daí, ficamos a vida inteira atuando de maneira informal. $E$ vários familiares foram se organizando nos estados com os Grupos Tortura Nunca Mais, Rio, São Paulo, Pernambuco, Bahia, Paraná, Alagoas e Goiás, posso estar esquecendo algum estado. 


\section{CRISTINA BUARQUE DE HOLLANDA:}

Iara, o governo Erundina na cidade de São Paulo, no final dos anos 1980, foi relevante para a luta de vocês, não foi? Você poderia comentar isso?

\section{IARA XAVIER PEREIRA:}

Com a eleição da Luiza Erundina como prefeita de São Paulo em 1988, temos apoio para aprofundar as buscas no Cemitério Dom Bosco. Até que recebemos a indicação da existência da Vala lá no cemitério, o que dá origem a uma CPI. Também é feito um convênio com a Unicamp, com o professor Badan Palhares para realizar as exumações e identificação dos restos mortais. Como não pude participar desses trabalhos porque estava longe, não tenho muita informação a respeito.

\section{CRISTINA BUARQUE DE HOLLANDA:}

Entre a descoberta de Perus e a criação da Comissão de Mortos e Desaparecidos Políticos, em 1995, houve a abertura de alguns arquivos estaduais de DOPs. Tenho duas perguntas a respeito disso. A primeira é se você vê alguma relação entre a repercussão do episódio de Perus e a abertura dos arquivos. $E$ a segunda é se esses arquivos tiveram impacto significativo (ou não) no movimento de familiares.

\section{IARA XAVIER PEREIRA:}

Vejo a abertura dos arquivos como resultado da redemocratização, a eleição de governadores não comprometidos com o regime militar e principalmente a luta dos familiares, que sempre pediram a abertura dos arquivos não só dos DOPs mas também os arquivos militares. Quando foi possível fazer pesquisa nesses arquivos vimos que eles tinham sido limpos, ou seja, retiram os documentos que eram importantes. 0 [arquivo do Dops] de Goiás, uma parte dele foi entregue em agosto ou setembro de 1995, foi um tapa na nossa cara. Ostensivamente tinha sido limpo. Tinha uma pasta do Alex, que nunca tinha ido a Goiás, mas estava vazia. Limpar um arquivo físico é difícil. Sempre sobrała-alguma coisa. No do Paraná, numa gavetinha lá, escrita "mortos", a Suzana achou nomes de desaparecidos. Sobrou. Agora, em relação aos arquivos do SNI é diferente. O habeas data é montado a partir dos pedidos individuais por um agente de inteligência, que informam o que querem, você não tem acesso as fichas.

\section{CRISTINA BUARQUE DE HOLLANDA:}

Iara, eu gostaria de tratar agora da Comissão Especial de Mortos e Desaparecidos [CEMDP]. Os familiares tiveram alguma participação no projeto de lei que criou a Comissão?

\section{IARA XAVIER PEREIRA:}

Acho que sim, mas acho que quem pesou mais foi D. Paulo [Evaristo Arns] e [José] Gregori. Foi uma demanda muito forte do pessoal ligado à Igreja e o Gregori [membro, durante a ditadura, da Comissão de Justiça e Paz de São Paulo, presidida por Dom Paulo Evaristo Arns] tinha uma sensibilidade para esse assunto, ele tinha a percepção de que precisava resolver a questão dos desaparecidos políticos, o que aconteceu com os desaparecidos políticos. Como eu estava em Mato Grosso, Gilney estava em campanha para deputado federal pelo PT, eu não participei muito desta parte [da criação da lei]. Gilney foi eleito deputado federal e decidimos vir para Brasília. Quando chegamos, acompanhamos todo o processo da tramitação [do projeto de lei]. Eu começo muito devagar e muito focada no 
[meu próprio] trabalho em Brasília. Mas surgiram demandas dos familiares pela facilidade que eu teria.

\section{CRISTINA BUARQUE DE HOLLANDA:}

Facilidade pelo fato de você estar em Brasília? E você trabalhava aonde?

\section{IARA XAVIER PEREIRA:}

Eu fazia um trabalho dentro da Câmara, acompanhando a reforma tributária, porque sou da Secretaria da Fazenda de Mato Grosso, e estava responsável por essa tarefa em Brasília. No assunto dos mortos e desaparecidos, nossa grande referência era o deputado Nilmário Miranda [PT], que tinha sido eleito presidente da Comissão de Direitos Humanos e Gilney, que participou dos debates das emendas, mas que não esteve tão presente porque se encontrou muito na temática dos povos indígenas e do meio ambiente e era o único deputado do PT que cuidava destes temas.

\section{CRISTINA BUARQUE DE HOLLANDA:}

Embora o Gilney não tenha se dedicado prioritariamente à causa dos mortos e desaparecidos, imagino que as facilidades do mandato dele tenham sido importantes para apoiar os familiares.

\section{IARA XAVIER PEREIRA:}

Sim, era na nossa casa que montávamos, sistematizávamos os dossiês para protocolar na CEMDP, além de servirmos de apoio para os familiares durante a estadia em Brasília. Naquela época, ninguém pagava as nossas passagens como foi [durante] o governo da Dilma, então vínhamos com os nossos recursos. Tentamos fazer um trabalho muito coletivo. Primeiro, ao reconhecer tudo o que havíamos conquistado com as aberturas dos arquivos dos DOPS do Rio, de São Paulo, de Pernambuco e do Paraná. Como o ônus da prova [dos crimes da ditadura] era dos familiares, fomos fazer um trabalho investigativo agrupando, juntando todas as informações que já tínhamos daquele militante, o que até então não havíamos feito, verificando o que podia estar faltando. $O$ que aquele laudo ou aquela foto diziam? Saiu no jornal? A gente tem depoimentos de presos? O trabalho do Brasil Nunca Mais foi muito importante para servir de base nas pesquisas que realizamos no arquivo do STM. A gente montou os dossiês cruzando essas informações. Decidimos também fazer uma pequena biografia que ia além da circunstância da morte. Onde estudou? Do que gostava? Eu pesquisava como era a vida da pessoa até ela se envolver com a militância. Eu acho importante, porque nunca me achei diferente dos outros jovens, salvo que nós tínhamos uma consciência e uma opção. Para mim, nós éramos nem monstros, nem anjos, nem deuses. Fomos um produto daquela época. Eu me dediquei muito: ligava para as mães para pedir fotografias, cartas, assim criei um vinculo muito próximo e forte com os familiares. Muitos familiares tinham raiva de quem era militante. A gente estava ali vivo. Mesmo inconscientemente eu imagino que... Quando eu visitei muitos deles, eu tinha um sentimento de culpa enorme porque eu estou viva e os parentes deles não. Imagino que todo sobrevivente tenha [culpa]. Para quem saiu [do país] deve ser pior. Eu fui embora quando tava grávida com uma expectativa de que ia voltar que se frustrou.

\section{CRISTINA BUARQUE DE HOLLANDA:}

Iara, voltando à criação da Comissão, qual era a visão dos familiares sobre ela? 


\section{IARA XAVIER PEREIRA:}

Tentamos alterar o projeto de lei sem conseguir. Ela não atendia a gente porque o ônus [da prova] ficou com a gente, e para realizar busca dos restos mortais nós é que tínhamos que indicar o local do possível sepultamento, dar indícios [para informar eventuais diligências da Comissão]. O ponto positivo da Comissão é que eles reconheciam os desaparecidos.

Reconhecia a nossa lista, a lista que foi sendo constituída pelos familiares ao longo dos anos, desde 75, com o primeiro congresso de anistia, de 78, com o primeiros dossiês. Não podemos dizer que não era um avanço. Mas, por outro lado, tinha esses percalços. Quando foram indicados os membros da CEMDP, a nossa representante dos familiares foi a Suzana Lisboa, que teve uma atuação fundamental na defesa e na aprovação dos processos.

\section{CRISTINA BUARQUE DE HOLLANDA:}

A maioria dos familiares aprovaram a participação de um representante das famílias na Comissão?

\section{IARA XAVIER PEREIRA:}

Sim, mas teve muita polêmica em relação ao recebimento da indenização. Em 28 de agosto de 1995, aniversário da Lei de Anistia, chamamos uma reunião de familiares em Brasília. Se não me engano, foram 84 familiares. Acho que foi a nossa maior reunião. Havia familiares que queriam aderir e outros achavam que não deviam porque era muito conflituoso para eles receber uma indenização sem receber os restos mortais, sem saber em que circunstância seu familiar foi assassinado e, no caso dos desaparecidos políticos, recebendo uma certidão de óbito com causa da morte "conforme Lei 9140/1995". Muitas famílias tinham dificuldade de aceitar reparação. Essa indenização era um tapa na cara d'a gente. Isso causou uma discussão sobre se era um avanço ou não esse tipo de responsabilização e indenização. Eu mesma tive dúvidas, depois com o resultado do nosso trabalho na comissão vi que foi um avanço. Gilney sempre defendeu dizendo que a reparação no mundo capitalista, que eles entendem como tal, é financeira. Bem ou mal, é o que o sistema põe. Eu mudo muito minha posição nessa reunião e voto pela participação dos familiares na comissão.

\section{CRISTINA BUARQUE DE HOLLANDA:}

Iara, podemos voltar aos dossiês para subsidiar os requerimentos na Comissão [CEMDP]? Como era o processo de montagem deles?

\section{IARA XAVIER PEREIRA:}

Formamos um grupo de familiares e militantes empenhados nessa tarefa. Durante um período Criméia [de Almeida] ficou comigo em Brasília trabalhando na montagem dos dossiês. Em São Paulo, tinha o Ivan Seixas, a Maria Amélia [Teles] e a Criméia, quando não estava em Brasília. No Rio, a Victória Grabois, a Cecilia Coimbra, o Togo Meireles e a Elisabeth Silveira. Em Santa Catarina, a Derley [de Luca]. Em Recife, a Maria do Amparo [Almeida Araújo], e no processo vários familiares ajudaram, participaram. Foi um trabalho coletivo. Tinha a biografia. Depois, a gente montava as circunstâncias da morte baseados na documentação de que dispúnhamos. No início, eu não assinava os dossiês, depois eu e Criméia passamos a assinar como Comissão de Familiares de Mortos e Desparecidos Políticos. Eu e Criméia trabalhamos como assessora da Suzana na comissão. Para deixar a 
coisa mais oficial, a Suzana solicitou nossa assessoria. Crimeia, quando esteve em Brasília, foi cedida pela prefeitura de São Paulo e eu sempre fiz trabalho voluntário.

Quando necessário, pedíamos diligências. Por exemplo, no caso do Iuri e do Alex, pedi exumação e exame de DNA, porque não tinha certeza se eram eles durante a exumação em outubro de 1980. E foi o pessoal argentino quem fez o exame de DNA. O laudo dos restos mortais, fui eu quem custeei. Fizemos o exame do Iuri, da Ana, do Marcos, da Zuzu Angel, por conta própria, porque o Miguel Reale [então presidente da CEMDP] não queria, não assumiu esse tipo de investigação porque podia chegar ao esclarecimento das circunstâncias [de morte] e a posição do governo era de não mexer com isso. No caso do Iuri, foi localizado o tiro de execução na nuca.

\section{CRISTINA BUARQUE DE HOLLANDA:}

[Miguel Reale] não queria a perícia?

\section{IARA XAVIER PEREIRA:}

É. Ele não determinou nenhuma exumação, só autorizou as buscas na região do Araguaia. Quando a equipe argentina - EAAF [Equipo Argentino de Antropologia Forense] veio [ao Brasil] para ir ao Araguaia [em missão da CEMDP], eu propus de fazer as exumações para elaborar um laudo e coletar material para exames de DNA. Aluguei um apartamento no Rio. Fizemos o Iuri, o Alex, a Ana, o Marquinhos, a Zuzu e o capitão Lamarca. A equipe argentina fez sem custos para os familiares, eles sempre foram muito solidários com a luta dos familiares.

\section{CRISTINA BUARQUE DE HOLLANDA:}

Esses laudos foram anexados aos dossiês?

\section{IARA XAVIER PEREIRA:}

Sim. No caso do Alex e Iuri, em finais de 1996 e inicio de 1997.

\section{CRISTINA BUARQUE DE HOLLANDA:}

Iara, e como foi para vocês conseguirem essas exumações? A própria Comissão [CEMDP] tinha autonomia para autorizar?

\section{IARA XAVIER PEREIRA:}

Sim, a Comissão podia requisitar mas não fez. No caso do Iuri e do Alex, o requerimento para exumação foi da minha mãe, destacando que seria para subsidiar o requerimento da Comissão. Nos outros casos, além da autorização dos familiares, tivemos o apoio do Nilmário Miranda como presidente da Comissão de Direitos Humanos da Câmara dos Deputados.

\section{CRISTINA BUARQUE DE HOLLANDA:}

E os peritos eram autônomos?

\section{IARA XAVIER PEREIRA:}

Eram. A EAAF já realizou trabalhos em várias partes do mundo, além da Argentina. Os dossiês foram montados da mesma forma. Nos casos em que tínhamos menos informações, como os do meu marido e da maioria, ficou mais restrito. Mas a sistemática [do dossiê] era a mesma: a biografia e a circunstância da morte com o que tínhamos recuperado de 
documentos, os laudos de necropsia. Esses são os laudos, com T de terrorista. A gente trabalhava com o que tinha. Inicialmente nós nos concentramos nos casos sobre os quais tínhamos mais elementos, mais provas, para criar uma convicção de que a versão apresentada pela repressão era falsa, era uma mentira, e isso foi muito importante.

\section{CRISTINA BUARQUE DE HOLLANDA:}

Hoje é uma coisa sabida, mas imagino que na época fosse ainda uma descoberta, uma revelação.

\section{IARA XAVIER PEREIRA:}

Sim, eles omitiam detalhes importantes dos dados periciais nos laudos, que dificultavam que um trabalho posterior identificasse o tempo do ferimento do tiro até a morte. Nós começamos, por exemplo; a perceber que não havia sobreviventes em nenhum dos tiroteios, muitos chegavam ao IML de cueca e meias. Em todos os nossos confrontos, morria um policial, quando muito, mas os nossos sempre morriam. Supomos que os sobreviventes feridos em confronto eram interrogados, quando havia condições [para isso], e depois eram executados. Então começamos a perceber um modus operandi da repressão.

Depois tivemos mais informação, porque o Iuri e a Ana Maria - que morreu com ele - têm uma ficha de identificação no DOPS onde consta: "identificado(a) em estado cadavérico". Foi um dos primeiros indícios que chamou nossa atenção, porque, se morreu na rua, o normal era o IML ou o rabecão levarem. Se morreram na rua mesmo, para que foram levados ao DOI [Destacamento de Operações de Informação] para serem identificados?! O do Iuri ainda está escrito que ele era míope, mas como eles teriam essa informação tão precisa se ele já chegou morto? Para analisar as fotos e os laudos, eu e Criméia tivemos a ideia de procurar ajuda de um perito criminal. Em 1996, o governador de Brasília era o Cristovam Buarque, do PT, que ajudou a conseguir um contato na policia civil com um perito, o Celso Neneve, que depois também assessorou a CNV. Ele começou ajudando os familiares e depois foi requisitado pela Comissão [CEMDP] para assessorar nessa área.

\section{CRISTINA BUARQUE DE HOLLANDA:}

A que época você se refere?

\section{IARA XAVIER PEREIRA:}

Ao período inicial da Comissão [CEMDP], que começou em janeiro de 1996. Em maio do mesmo ano, quando terminou o prazo legal para os requerimentos. Tínhamos conseguido protocolar 377 requerimentos referentes a 366 pessoas (teve mais de um requerimento para a mesma pessoa), sendo 132 desaparecidos que constavam no anexo I da lei. Com nosso trabalho procurávamos, nessa primeira etapa, contestar as versões de "suicídios", "atropelamentos", "tentativas de fuga" e tiroteios. As dificuldades eram enormes, inclusive pelo nosso envolvimento emocional com o assunto, e porque os principais arquivos da repressão não tinham sido e não foram abertos até hoje.

Aos poucos fomos conseguindo provar que a versão oficial era falsa, e numa segunda fase começamos a discutir as mortes com versão de "morte em tiroteio ao resistir a prisão", na rua. Abriu-se uma discussão sobre a interpretação da alínea b do artigo $4^{\circ}$ da lei "em dependências policias ou assemelhadas", que se acirrou quando do julgamento dos processos de Carlos Marighella e Carlos Lamarca, em novembro de 1996, quando prevaleceu o entendimento de que os mortos poderiam ter sido presos e não foram. Ou seja, importava 
como morreu, e não o local. A pessoa não tinha que estar dentro de uma dependência policial. Várias associações de juristas deram parecer neste sentido. O Miguel Reale foi muito importante nesse momento. A postura dele era assim: era favorável a nós, desde que não fossemos chegar a identificar [os responsáveis pelos crimes], querer punir. Acho que se não fosse por ele, não teríamos avançado na interpretação das "dependências assemelhadas" como avançamos. Nessa época, foram indeferidos os processos em que a morte se deu fora do período de abrangência da lei, que era até 15 de agosto de 1979 . Os casos posteriores a esta data foram acolhidos com a alteração da lei em agosto de 2002, quando se passou a considerar as mortes até 5 de outubro de 1988, incluindo os casos de suicídio quando da eminência de ser preso e/ou em consequência das torturas sofridas, e também as mortes em passeatas - que foram reconhecidos com alteração da lei em 2004.

\section{CRISTINA BUARQUE DE HOLLANDA:}

Como você e os familiares em geral avaliam os governos Lula (2003-2011) em relação à pauta dos mortos e desaparecidos?

\section{IARA XAVIER PEREIRA:}

Tínhamos muita expectativa com o governo Lula, que não se concretizaram. A Suzana ficou como representante até novembro de 2005, quando já tinham se passado dez anos de atuação da Comissão. Nessa época, ela, Criméia e outros familiares consideraram que devíamos deixar de ter representante na Comissão, já que o governo estava esvaziando a Comissão quando criou, em 2003, sem nos consultar, um grupo interministerial para localização dos militantes assassinados na "guerrilha do Araguaia", não avançaram na identificação e punição dos culpados, abertura de todos os arquivos inclusive os das Forças Armadas. Eu estava de acordo com todos os motivos delas, mas achava que naquele momento não devíamos deixar de participar na Comissão. Ainda tínhamos mais ou menos 38 processos a serem apreciados e tínhamos que concluir o julgamento de todos eles. Essa foi a minha posição, também defendeu essa posição, posso deixar de citar algum grupo ou familiar, mas com certeza o Grupo Tortura Nunca Mais do Rio, da Bahia e outros familiares. Afinal, o que prevaleceu foi a decisão de marcar uma posição e romper com o governo. Quem assumiu a representação, no lugar da Suzana, foi Diva Santana, que era irmã de uma desaparecida política na guerrilha do Araguaia. De uma forma ou de outra, os familiares continuaram a luta.

\section{CRISTINA BUARQUE DE HOLLANDA:}

Iara, como você enxerga o movimento mais ou menos recente, do qual inclusive o Gilney tomou parte importante, no sentido de incorporar indígenas e camponeses como atingidos pela violência da ditadura?

\section{IARA XAVIER PEREIRA:}

Em princípio, nós, familiares, somos muito sectários em relação a isso. Talvez sectários não seja a melhor palavra, mas éramos muito ciosos da nossa lista, dos nossos mortos. Sei que muitos familiares tinham muita restrição. Uma vez, Gilney [na altura em que coordenava 0 Projeto Direito à Memória e à Verdade, na Secretaria de Direitos Humanos, 2011-2014], quando estávamos discutindo a criação da CNV, organizou um seminário muito bom ampliando essa visão de quem são os atingidos. Veio um peruano que começou a falar das graves violações [de direitos humanos] no Peru, onde os atingidos ultrapassavam em muito os militantes de organizações políticas. Aqui no Brasil, Gilney focou muito nos camponeses e 
nos povos indígenas e foi muito crítico da CNV porque ela deixou muito a dever mesmo em relação a esse assunto. Quais eram as violações [de direitos no país]? Não eram só prisão e morte por militância política. São várias as formas de violações de direitos humanos. Um camponês que resistiu a sair dali [da sua terra] não era um ato político? A tribo que se recusa a sair de suas terras não é um ato político? É um ato político, claro. Não é uma atividade política partidária, mas é expressão de uma posição política, de posição contra aqueles que querem vitimá-los, de resistência ao sistema.

\section{CRISTINA BUARQUE DE HOLLANDA:}

Iara, me parece que um dos aliados importante na luta de vocês foi o Ministério Público Federal. Você poderia comentar a atuação deles?

\section{IARA XAVIER PEREIRA:}

A partir de 2008/2009 os procuradores de São Paulo apresentam as primeiras ações penais e principalmente a partir de 2011, quando é criado o Grupo de Trabalho Justiça de Transição - GTJT. Isso aconteceu depois de uma derrota e uma vitória nossa. A derrota foi quando o STF, em abril 2010, declara a constitucionalidade da lei de anistia [de 1979] no que refere à inclusão dos agentes da repressãoiv. A vitória foi na Corte Interamericana de Direitos Humanos, em novembro de 2011, quando o Brasil foi condenando no caso "Gomes Lund e outros vs Brasil"v, definindo que os crimes de tortura, assassinatos de prisioneiros e desaparecimentos forçados não são passiveis de anistia e prescrição, devem ser investigados criminalmente e os agentes da repressão envolvidos submetidos a juízo.

\section{CRISTINA BUARQUE DE HOLLANDA:}

Iara, ainda tratando dos atores cuja atuação é próxima à luta dos familiares, qual é a sua impressão sobre a Comissão de Anistia? As categorias profissionais organizadas moldaram muito o perfil da lei [de criação da Comissão de Anistia]. Eles vieram [para Brasília] durante o processo de tramitação da lei. Vieram organizados, começaram a criar as associações de anistiados no Brasil inteiro. Como resultado, a lei ficou muito voltada para uma reparação previdenciária. Essa atuação começa a mudar na gestão do então ministro de Justiça, Tarso Genro, que nomeia o Paulo Abrão para presidir a comissão. Eles tiraram os julgamentos de Brasília, e por meio de caravanas [as caravanas de anistiavi] foi a várias cidades do pais, divulgando e resgatando a memória da resistência daqueles atingidos. A Comissão também realizou sessões temáticas. Eu sugeri uma sessão para discutir a perseguição aos filhos dos militantes. Muitos deles foram presos, banidos, nasceram no exterior sem direito à cidadania brasileira. A partir daí, nós começamos a ter um diálogo com a Comissão [de Anistia] defendendo sempre que tivesse critérios políticos, que se respeitasse a ordem de protocolos e que se fizessem essas sessões temáticas. O Paulo politizou a comissão, fez as caravanas, fez seminários. E aí nós mantivemos uma pareceria, ligados por princípios. Nós participamos de algumas caravanas [de anistia]. Ele abriu muito espaço para o que nós defendíamos. As caravanas serviram para mostrar um outro lado, político, que não era apenas o lado da reparação financeira.

\section{CRISTINA BUARQUE DE HOLLANDA:}

E, para terminarmos, qual foi sua impressão sobre a CNV? 


\section{IARA XAVIER PEREIRA:}

Olha, quando chegou a CNV, a gente vinha de muita frustração com o governo Lula. Eu não cheguei a ficar frustrada com [o governo da] Dilma [Roussef] (2011-2016) porque eu não tinha expectativa em relação a ela. Em toda a trajetória dela, ela nunca colocou um prego, nunca teve uma aproximação mínima [com os familiares na luta]. Agora, um dos saldos positivos da CNV foi colocar em pauta os temas de memória, verdade. Mas aí não foi a Comissão sozinha. A Maria do Rosário [então Secretária de Direitos Humanos] e o Gilney organizaram a sociedade civil praticamente no Brasil todo. Gilney ia e reunia ex-presos, militantes dos direitos humanos e dizia: "para essa Comissão [CNV] avançar, precisa ter comissão da sociedade civil". Ele teve essa visão e a Maria do Rosário comprou essa ideia. Foi um saldo positivo porque colocou em pauta esse assunto, não só dos mortos e desaparecidos políticos. A gente sempre foi muito invisível. O nosso tema nunca teve em pauta, sempre foi escanteado. Para mim, uma das melhores funções da CNV foi justamente fazer com que as pessoas discutissem, falassem do assunto. Mas, em relação aos nossos mortos e desaparecidos políticos pouco avançou, a CNV contava como ponto de partida de todo acervo da CEMDP e praticamente não investigaram nada. Para nós, familiares, dois pontos atualmente são fundamentais: a localização e o esclarecimento do destino dos corpos; e a responsabilização penal dos agentes envolvidos.

\section{CRISTINA BUARQUE DE HOLLANDA:}

Então a luta dos familiares continua?

\section{IARA XAVIER PEREIRA:}

Sim, essa luta ainda não acabou, continuamos lutando por justiça penal para os torturadores, pela localização de todos os restos mortais dos nossos desaparecidos políticos, por saber " Como, Quando, Onde" foram mortos nossos familiares.

\section{CRISTINA BUARQUE DE HOLLANDA:}

Muito obrigada por esta entrevista, Iara.

\section{Cite esta entrevista}

XAVIER, Iara 2019. Entrevista com Iara Xavier, conduzida por Cristina Buarque de Hollanda. Revista Estudos Políticos: a publicação semestral do Laboratório de Estudos Hum(e)anos (UFF).Rio de Janeiro, Vol.10 |N.2, pp. 47-62, dezembro de 2019. 


\section{Notas}

1. Alex foi assassinado pela repressão em janeiro de 1972 e Iuri cinco meses depois, em junho do mesmo ano. As versões oficiais alegavam, como de praxe, que ambos haviam falecido em decorrência de confrontos a bala com a polícia. Segundo perícia de laudos e documentos da época, realizada na década de 90 , as lesões a tiros nos dois não eram compatíveis com a versão da morte em tiroteio. Marcas nos corpos indicam que os dois foram torturados e executados pela repressão. Para detalhes sobre os casos, ver: http://memoriasdaditadura.org.br/biografias-daresistencia/iuri-e-alex-de-paula-xavier-pereira/

2. A versão oficial da morte de Arnaldo foi divulgada nos jornais Folha da Tarde, Jornal da Tarde, Folha de São Paulo e O Estado de São Paulo, em 16 de março de 1973. Ela alegava que, ao receber voz de prisão, na Rua Caquito, no bairro da Penha, em São Paulo, Arnaldo reagiu com tiros e provocou os disparos que 0 atingiram. Ele estava acompanhado de Francisco Emmanuel Penteado e Francisco Seiko Okama, todos mortos na ocasião. Para informações sobre as evidências de falsidade da versão da morte em tiroteio, ver:

http://memoriasdaditadura.org.br/memorial/arnaldocardoso-rocha/

3. Em 1998, Iara conseguiu a comprovação do Iuri, por exame de DNA. Quanto a Alex, somente conseguiu depois de 42 anos da sua morte, em março de 2014, também por exame de DNA.

4. Iara se refere à votação da Arguição de Descumprimento de Preceito Fundamental (ADPF) 153, apresentada ao Supremo Tribunal Federal pelo Conselho Federal da Ordem dos Advogados do Brasil com o questionamento da anistia aos representantes do Estado que, durante o regime militar, praticaram atos de tortura.

5. Trata-se de ação iniciada na Justiça Federal em 19 de fevereiro de 1982 por 22 familiares de desaparecidos do Araguaia. Diante da falta de respostas do Estado brasileiro à interpelação dos familiares, a Corte julgou o caso e proferiu sentença condenatória.

6. As caravanas de anistia foram eventos itinerantes organizados pela Comissão de Anistia em localidades públicas de todo país. Elas tiveram o intuito de julgar pedidos individuais de anistia e fazer dos julgamentos um ato de memória sobre a ditadura, com 
ENTREVISTA COM IARA XAVIER

REVISTA ESTUDOS POLÍTICOS

Vol. 10 | N.2

ISSN 2177-2851

Cristina Buarque de Hollanda

testemunhos e pedidos públicos de desculpas proferidos pelo presidente da Comissão, Paulo Abrão. 